\title{
Lung Injury Produced by Moderate Lung Overinflation in Rats
}

\author{
By Robert E. Cilley, James Y. Wang, and Arnold G. Coran \\ Hershey, Pennsy/vania and Ann Arbor, Michigan
}

\begin{abstract}
- In models using both intact animals and isolated lungs of rats, rabbits, lambs, and dogs, application of high airway pressure and resultant lung overdistension has been shown to cause lung injury. Under pathological conditions, the more normal portions of the lung may be subjected to relative overdistension when supranormal airway pressures are used. A small animal model of lung overdistension is presented here to demonstrate that lung injury can be caused by moderate lung overdistension. Aats were anesthetized with Ketamine and pentobarbital. A tracheostomy was performed and arterial and central venous catheters placed. The animal was placed in a plethysmograph and an infant ventilator was used to provide mechanical ventilation. In the first experiment, animals in group $A$ ( $n=6$, control) were ventilated at tidal volume (TV) of $5 \mathrm{~mL} / \mathrm{kg}$ for 5 hours. Animals in group B $(n=6)$ were ventilated at TV $15 \mathrm{~mL} / \mathrm{kg}$ for 60 minutes and then were returned $T V$ of $5 \mathrm{~mL} / \mathrm{kg}$ for the remainder of the experiment. Animals in group $C(n=5)$ were ventilated at TV $20 \mathrm{~mL} / \mathrm{kg}$ for 60 minutes and then returned to $T V 5 \mathrm{~mL} / \mathrm{kg}$. Static lung compliance and arterial blood gasses were measured. Wet and dry lung weight were obtained after sacrifice. In the second experiment, animals in group $D$ ( $n=4$, control) were ventilated at TV $5 \mathrm{~mL} / \mathrm{kg}$ for 240 minutes and killed. Animals in group $E(n=4)$ were ventilated at TV $20 \mathrm{~mL} / \mathrm{kg}$ for 60 minutes, returned to TV $5 \mathrm{~mL} / \mathrm{kg}$, and killed at 240 minutes. Fluorescein-labeled albumin was administered to each animal prior to mechanical ventilation. At sacrifice bronchoalveolar lavage was performed on the right lung. The left lung was fixed for microscopy. Hematocrit, venous oxygenation, and temperature remained stable throughout the experimental period. Group $C$ animals had an elevated $\mathrm{PO}_{2}$ during high volume mechanical ventilation. By the conclusion of the experiment, animals in group $B$ and $C$ were acidotic. Lung compliance fell in all groups. Wet/dry lung weight and dry lung weight/ body weight ratios increased in the TV $20 \mathrm{~mL} / \mathrm{kg}$ group. Analysis of bronchoalveolar lavage fluid for fluoresceine in order to detect capillary-alveolar leak revealed no difference between TV $5 \mathrm{~mL} / \mathrm{kg}$ (control) and TV $20 \mathrm{~mL} / \mathrm{kg}$ animals. There was slight perivascular edema in the TV $20 \mathrm{~mL} / \mathrm{kg}$ specimens. We have demonstrated in a whole animal preparation in rats that lung injury can result from mechanical overdistension with as little as $20 \mathrm{~mL} / \mathrm{kg}$ for 1 hour.

Copyright $\odot 1993$ by W.B. Saunders Company
\end{abstract}

INDEX WORDS: Lung injury, mechanical ventilation.

From the Division of Pediatric Surgery, The Milton $S$. Hershey Medical Center, Pennsylvania State University, Hershey, PA, and the Section of Pediatric Sungery, University of Michigan Medical Center, Ann Arbor, MI.

Presented at the 23rd Annual Meeting of the American Pediatric Surgical Association, Colorado Springs, Colorado, May 13-16, 1992.

Address reprint requests to Robert E. Cilley, MD, Division of Pediatric

Surgery, The Milton S. Hershey Medical Center, Hershey, PA 17033.

Copyright $\odot 1993$ by W.B. Saunders Company

0022-3468/93/2803-0035\$03.00/0
$\mathbf{R}$ ESPIRATORY failure and its treatment are part of the common experience of every physician. Respiratory failure may be brief and reversible (eg, pharmacological paralysis during surgery), or profound (eg, respiratory distress syndrome in association with multiple organ failure) requiring prolonged use of mechanical ventilation or even extracorporeal life support. Positive-pressure mechanical ventilation is commonly used to support the oxygenation and ventilation functions of failing lungs. Although positive-pressure mechanical ventilation is used as part of the care for respiratory failure, it may under some circumstances be a culprit in the progression of lung injury.

Ample evidence exists from mammalian studies that lung overdistension causes lung injury. ${ }^{1-9}$ In models using both intact animals and isolated lungs of rats, rabbits, lambs, and dogs, application of high airway pressure and resultant lung overdistension has been shown to cause lung injury characterized by: (1) impaired gas exchange, primarily hypoxia; (2) altered lung compliance and decreased functional residual capacity; (3) visible changes of atelectasis and hemorrhage; (4) progressive appearance of pulmonary infiltrates seen radiographically; (5) histological changes progressing from perivascular edema to interstitial edema (associated with endothelial cell damage) to alveolar edema (associated with epithelial cell injury); (6) increased microvascular permeability and filtration pressure, and increased lung lymph flow and lung lymph protein flux; and (7) decreased surfactant levels and increased surface tension of lung extracts. Most studies have been acute and rapidly lethal; using tidal volumes that are never used in the mechanical ventilation of patients. However, under pathological conditions that may include inhomogeneity of lung injury, the more normal portions of the lung may be subjected to relative overdistension when supranormal airway pressures are used. Previous work in rats has demonstrated that ventilation with tidal volumes of $30 \mathrm{~mL} / \mathrm{kg}$ or more has resulted in immediate, severe lung injury. ${ }^{2.4}$ In a small animal model of lung overdistension, we have asked the question, what is the minimal level of overdistension that is associated with lung injury? A series of experiments is presented here to demonstrate that lung injury can be caused by moderate lung overdistension in rats. 


\section{MATERIALS AND METHODS}

\section{Animal Preparation/Instrumentation}

Five hundred-gram male Sprague-Dawley rats were anesthetized with intramuscular Ketamine $(100 \mathrm{mg} / \mathrm{kg})$ followed by intraperitoneal pentobarbital $(20 \mathrm{mg} / \mathrm{kg})$. A cervical tracheostomy was performed using a thin-walled 14-gauge Teflon catheter. The catheter was secured by ligature around the trachea. A femoral or common carntid artery catheter (PE-50 tubing) was placed for continuous blood pressure monitoring and blood gas sampling. In some animals a $4 \mathrm{~F}$ fiber-optic catheter was placed in the right atrium via the external jugular vein and used for continuous monitoring of central venous oxygen saturation (Oximetrix IV, $\mathrm{SO}_{2}$ computer; Abbott Critical Care, North Chicago, IL).

Each animal was placed in a plethysmograph chamber designed to measure tidal volumes from 1 to $20 \mathrm{~mL}$ (Buxco Electronics, Sharon, (T). By analyzing the signal from a pressure transducer attached to a small plexiglass chamber with a pneumotachograph, an analog voltage signal proportional to the tidal volume is created, allowing precise tidal volume measurements to be made (Fig 1). A time-cycled, pressure-limited infant ventilator was used to provide mechanical ventilation (Sechrist or Bear Cub, Bear Medical Systems, Riverside, CA). A buffered isotonic saline solution was infused intravenously at $6 \mathrm{~mL} / \mathrm{kg} / \mathrm{h}$ throughout the experiment.

\section{Experimental Protocol, Experiment 1}

In the first experiment, three groups of animals were studied. Animals in group $A$ ( $n=6$, control) were ventilated at tidal volume (TV) $5 \mathrm{~mL} / \mathrm{kg}$. Ventilator settings used to provide this TV were: peak inspiratory pressure (PIP) $8 \mathrm{~cm} \mathrm{H}_{2} \mathrm{O}$, positive end-expiratory pressure (PEEP) $2 \mathrm{~cm} \mathrm{H}_{2} \mathrm{O}$, inspiratory time (IT) 0.2 seconds, respiratory rate $(\mathrm{RR}) 86 / \mathrm{min}$, ventilator circuit flow $4 \mathrm{~L} / \mathrm{min}$. These settings were maintained for 5 hours. Static lung compliance was measured at $\mathrm{t}=0$ minutes (after instrumentation but prior to starting mechanical ventilation), at 60 minutes, and at 300 minutes. Arterial blood gases were measured at 0, 30, and 300 minutes (Radiometer ABL 2; Copenhagen, Denmark).

Animals in group $B(n=6)$ wcre ventilated at TV $15 \mathrm{~mL} / \mathrm{kg}$ for 60 minutes with ventilator settings of: PIP $12 \mathrm{~cm} \mathrm{H}_{2} \mathrm{O}$, PEEP $2 \mathrm{~cm}$ $\mathrm{H}_{2} \mathrm{O}$, IT 0.50 seconds RR 40 , flow $4 \mathrm{~L} / \mathrm{min}$. After 60 minutes, the TV was returned to $5 \mathrm{~mL} / \mathrm{kg}$ for the remainder of the experiment. Lung compliance measurement and arterial blood gas analysis were performed as for group $A$.

Animals in group $\mathrm{C}(\mathrm{n}=5)$ were ventilated at $\mathrm{TV} 20 \mathrm{~mL} / \mathrm{kg}$ for 60 minutes, with ventilator settings of: PIP $18 \mathrm{~cm} \mathrm{H} \mathrm{H}_{2} \mathrm{O}$, PEEP $2 \mathrm{~cm}$ $\mathrm{H}_{2} \mathrm{O}$, IT 0.50 seconds, $\mathrm{RR} 40$, flow $4 \mathrm{~L} / \mathrm{min}$, then returned to TV 5 $\mathrm{mL} / \mathrm{kg}$ for the remainder of the experiment. Lung compliance

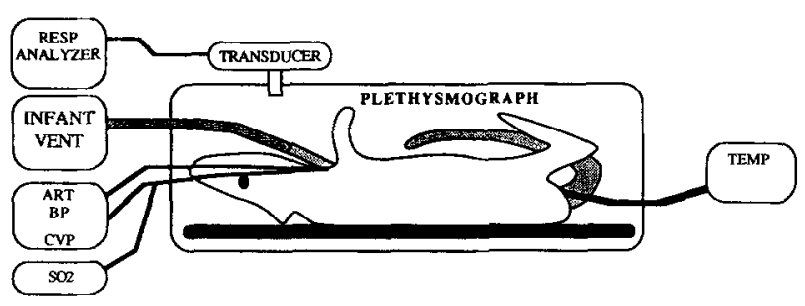

Fig 1. Experimental set-up. Respiratory analyzer derives tidal volume from pressure changes in open plethysmograph. Time-cycled, pressure-limited infant ventilator adjusted to provide desired tidal volume. Monitoring includes arterial blood pressure, central venous blood pressure, central venous oximetry, and core body temperature. measurement and arterial blood gas analysis were performed as for group A.

At the conclusion of the experiment the animals were killed by inferior vena cava transection. The right lung was excised (4 lobes in rats) through a median sternostomy and the hilum trimmed to the level of lung parenchyma. This specimen was blotted dry and weighed. The specimen was then dried in a $70^{\circ} \mathrm{C}$ oven for 3 days and a dry weight obtained.

Static lung compliance was calculated by briefly hyperventilating the animal with $6 \mathrm{~mL} / \mathrm{kg}$ volumes of air and the airway opened to atmospheric pressure (thus, the starting volume was the functional residual capacity al $\mathrm{p}_{\text {atm }}$ ). Step-wise injection of $1 \mathrm{~mL}$ of air to a total of $6 \mathrm{~mL}$ was performed while monitoring the airway pressure. A pressure-volume compliance curve was constructed. The slope of this curve is a measure of compliance. Compliance values were normalized to body weight.

\section{Experimental Protocol, Experiment 2: (Capillany-Alveolar Leak, Histology)}

In the second experiment, two groups of animals were studied. Animals in group $\mathrm{D}(\mathrm{n}=4$, control) were ventilated at TV 5 $\mathrm{mL} / \mathrm{kg}$ for 240 minutes, then killed. Animals in group $\mathrm{E}(\mathrm{n}=4)$ were ventilated at TV $20 \mathrm{~mL} / \mathrm{kg}$ for 60 minutes, returned to TV 5 $\mathrm{mL} / \mathrm{kg}$, and killed at 240 minutes. At the onset of mechanical ventilation, $5 \mathrm{mg}$ of fluorescein-labeled albumin (Molecular Probes, Fugene, $O R$ ) was administered intravenously in $1 \mathrm{~mL}$ of phosphatebuffered saline. At the termination of the experiment, a serum sample was obtained for fluorescence measurement. A midline thoracotomy/laparotomy was performed and the abdominal vessels transected. The ventilator was turned off and continuous positive airway pressure applied. The right mainstem bronchus was ligated at the carina and a catheter inserted through a bronchotomy for bronchoalveolar lavage (BAL). The right lung was infused with $6 \mathrm{~mL}$ of buffered saline which was then withdrawn. Five milliliters of lavage fluid was recovered in each experiment. This specimen was analyzed for fluorescence.

The left lung was then prepared for microscopy fixation. The ventilator was adjusted to provide an airway pressure of $12 \mathrm{~cm}$ $\mathrm{H}_{2} \mathrm{O}$, fully distending the lungs. The heart-lung vasculature was then isolated by ligating the inferior vena cava and left superior vena cava, and securing the right superior vena cava around the right atrial catheter with the ligature. The left atrium was opened and the right heart perfused via the right atrial catheter using a solution of $4 \%$ glutaraldehyde and $0.1 \mathrm{~mol} / \mathrm{L}$ cacodylate buffer. The perfusion pressure of the fixative remained at about $60 \mathrm{~mm}$ Hg. After 10 minutes of perfusion, the left lung was excised and a $1.5-\mathrm{mm}$ slice taken from the midlung. This specimen was then soaked in fixative for 2 hours, cut in $1.5-\mathrm{mm}$ cubes, and placed in cold cacodylate buffer. These specimens were further fixed with osmium tetroxide, dehydrated with ethanol and embedded with epoxy resin. Thick sections were stained with methylene blue/ azure II and examined under light microscopy.

A serum sample and BAL fluid were analyzed for fluorescence using an automated excitation fluorometer (Cyto Flor 2300). Fluorescence was measured using an excitation filter of $450 \mathrm{~nm}$ and an emission filter of $530 \mathrm{~nm}$.

\section{Data Analysis and Animal Care}

Group means were analyzed for statistical significance using Student's paired $t$ test. Statistical significance was assigned for $P$ values less than 0.05 .

Animal care was supervised and experimental protocols approved by the University Committee on the Use and Care of 
Animals, University of Michigan Medical School, Ann Arbor Michigan or the Institutional Animal Care and Use Committee, The Pennsylvania State University, Hershey, PA.

\section{RESULTS}

Physiologic parameters of animals ventilated at normal and high tidal volumes are given in Table 1.

Arterial blood gas values are shown in Table 2 . Arterial $\mathrm{pO}_{2}$ remained stable. There was no significant difference in the initial and final values among any of the groups. Group C $(20 \mathrm{~mL} / \mathrm{kg}$ TV $)$ animals had an elevated $\mathrm{pO}_{2}$ during high volume mechanical ventilation. Although mechanical ventilator rate was decreased, significant hypocarbia occurred during ventilation at 15 and $20 \mathrm{~mL} / \mathrm{kg}$. As expected the animals were alkalotic as well. By the conclusion of the experiment, animals in group $\mathrm{B}$ and $\mathrm{C}$ were slightly acidotic.

Lung compliance fell in control animals as well as those ventilated at 15 and $20 \mathrm{~mL} / \mathrm{kg}$, although the decrease was statisticly significant only in the TV 20 $\mathrm{mL} / \mathrm{kg}$ group (Table 3 ).

Wet/dry lung weight, a sensitive indicator of lung edema, was increased in the TV $20 \mathrm{~mL} / \mathrm{kg}$ group (Table 4). Dry lung weight/body weight ratio was considerably higher in the TV $20 \mathrm{~mL} / \mathrm{kg}$ group but failed to reach statistical significance $(P=.13)$ due to a single "outlier" value in the control group. However, no data were eliminated for the purposes of statistical analysis.

Analysis of BAL fluid for an intravascular tracer in order to detect capillary-alveolar leak revealed no difference between TV $5 \mathrm{~mL} / \mathrm{kg}$ (control) and TV 20 $\mathrm{mL} / \mathrm{kg}$ animals (Table 4 ).

\begin{tabular}{|c|c|c|c|}
\hline & $\begin{array}{c}\text { Group } A \\
(\mathrm{TV}=5 \mathrm{~mL} / \mathrm{kg})\end{array}$ & $\begin{array}{c}\text { Group B } \\
(T V=15 \mathrm{~mL} / \mathrm{kg})\end{array}$ & $\begin{array}{c}\text { Group C } \\
(\mathrm{TV}=20 \mathrm{~mL} / \mathrm{kg})\end{array}$ \\
\hline Initial Hct & $43 \pm 2$ & $43 \pm 4$ & $42 \pm 2$ \\
\hline \multirow[t]{2}{*}{ Final Hct } & $45 \pm 4$ & $38 \pm 4^{*}$ & $40 \pm 2$ \\
\hline & $\begin{array}{c}\text { Group D } \\
(\mathrm{TV}=5 \mathrm{~mL} / \mathrm{kg})\end{array}$ & & $\begin{array}{c}\text { Group } E \\
(\mathrm{~T}=20 \mathrm{~mL} / \mathrm{kg})\end{array}$ \\
\hline Initial $\mathrm{S}_{\mathrm{cv}} \mathrm{O}_{2}$ & $70 \pm 1$ & & $68 \pm 14$ \\
\hline Injury $\mathrm{S}_{t v} \mathrm{O}_{2}$ & $69 \pm 1$ & & $68 \pm 7$ \\
\hline Final $\mathrm{S}_{\mathrm{cr}} \mathrm{O}_{2}$ & $65 \pm 4$ & & $69 \pm 5$ \\
\hline Initial MBP (mm Hg) & $112 \pm 17$ & & $129 \pm 31$ \\
\hline Injury MBP (mm Hg) & $100 \pm 16$ & & $122 \pm 8$ \\
\hline Final MBP $(\mathrm{mm} \mathrm{Hg})$ & $98 \pm 22$ & & $108 \pm 22$ \\
\hline Initial temperature & $35.6 \pm 0.8$ & & $36.9 \pm 0.8$ \\
\hline Final temperature & $34.8 \pm 0.5$ & & $35.6 \pm 0.5$ \\
\hline \multicolumn{4}{|c|}{ NOTE. Data given as mean $\pm \mathrm{SD}$} \\
\hline
\end{tabular}

Table 2. Arterial Blood Gas Measurements From Animals Ventilated at Different Tidal Volumes

\begin{tabular}{|c|c|c|c|}
\hline & $\begin{array}{c}\text { Group A } \\
\text { (TV }-5 \mathrm{~mL} / \mathrm{kg})\end{array}$ & $\begin{array}{c}\text { Group B } \\
(\mathrm{TV}-15 \mathrm{~mL} / \mathrm{kg})\end{array}$ & $\begin{array}{c}\text { Group C } \\
(T V=20 \mathrm{~mL} / \mathrm{kg})\end{array}$ \\
\hline Initial $\mathrm{PaO}_{2}(\mathrm{~mm} \mathrm{Hg})$ & $100 \pm 7$ & $102 \pm 13$ & $100 \pm 6$ \\
\hline \multicolumn{4}{|l|}{ Midinjury $\mathrm{PaO}_{2}$} \\
\hline$(\mathrm{mm} \mathrm{Hig})$ & $104 \pm 21$ & $112 \pm 8$ & $119 \pm 6^{*}$ \\
\hline Final $\mathrm{PaO}_{2}(\mathrm{~mm} \mathrm{Hg})$ & $107 \pm 12$ & $107 \pm 10$ & $103 \pm 8$ \\
\hline Initial $\mathrm{PaCO}_{2}(\mathrm{~mm} \mathrm{Hg})$ & $45 \pm 2$ & $42 \pm 2$ & $44 \pm 3$ \\
\hline \multicolumn{4}{|l|}{ Midinjury $\mathrm{PaCO}_{2}$} \\
\hline$(\mathrm{mm} \mathrm{Hg})$ & $46 \pm 4$ & $32 \pm 3^{*}$ & $29 \pm 2^{*}$ \\
\hline Final $\mathrm{PaCO}_{2}(\mathrm{~mm} \mathrm{Hg})$ & $42 \pm 6$ & $37 \pm 4^{*}$ & $45 \pm 4$ \\
\hline Initial pH & $7.33 \pm .03$ & $7.35 \pm .03$ & $7.36 \pm .02$ \\
\hline Midinjury pH & $7.30 \pm .06$ & $7.43 \pm .06^{*}$ & $7.50 \pm .04^{*}$ \\
\hline Final pH & $7.30 \pm .08$ & $7.30 \pm .04^{*}$ & $7.26 \pm .04^{*}$ \\
\hline
\end{tabular}

NOTE. Data given as mean $\pm \mathrm{SD}$.

$* P<.05$ v initial value in each group.

There were few features that distinguish the groups histologically. In the control lungs, the alveoli were normal in appearance and no perivascular edema was present. There were few intraalveolar cells (Fig 2). The lungs ventilated at a TV of $20 \mathrm{~mL} / \mathrm{kg}$ showed slight perivascular edema and some intraalveolar red blood cells (Fig 3). These finding were present throughout TV $20 \mathrm{~mL} / \mathrm{kg}$ specimens.

\section{DISCUSSION}

We have asked the question, what is the minimal level of overdistension that causes lung injury in rats? Previous studies have shown that severe, lethal injury will result with tidal volumes of $30 \mathrm{~mL} / \mathrm{kg} .{ }^{2-4}$ Rats respire spontaneously with tidal volumes of approximately $5 \mathrm{~mL} / \mathrm{kg}$. We ventilated rats with positivepressure mechanical ventilation at $15 \mathrm{~mL} / \mathrm{kg}$ and 20 $\mathrm{mL} / \mathrm{kg}$. Elevated wet $/$ dry lung weight ratios and dry-lung/body-weight ratios provided clear evidence of injury from $20 \mathrm{~mL} / \mathrm{kg}$ overinflation for 1 hour. No lung weight changes were produced with $15 \mathrm{~mL} / \mathrm{kg}$ ventilation for 1 hour. Wet/dry weight and dry-weight/ body-weight ratios closely parallel other indicators of lung edema including ${ }^{125}$ I-albumin leakage, sodium space, and extravascular lung water. ${ }^{3,4}$ They do not distinguish between fluid accumulation from in-

Table 3. Static Lung Compliance of Animals Ventilated at Different Tidal Volumes

\begin{tabular}{lccc}
\hline & $\begin{array}{c}\text { Group A } \\
(\mathrm{TV}=5 \mathrm{~mL} / \mathrm{kg})\end{array}$ & $\begin{array}{c}\text { Group B } \\
(\mathrm{TV}=15 \mathrm{~mL} / \mathrm{kg})\end{array}$ & $\begin{array}{c}\text { Group C } \\
(\mathrm{TV}=20 \mathrm{~mL} / \mathrm{kg})\end{array}$ \\
\hline Initial $\mathrm{C}_{\mathrm{s}}$ & $1.3 \pm .5$ & $1.2 \pm .1$ & $1.1 \pm .1$ \\
After injury $\mathrm{C}_{\mathrm{s}}$ & $1.1 \pm .4$ & $1.3 \pm .3$ & $1.1 \pm .2$ \\
Final $\mathrm{C}_{\mathrm{s}}$ & $1.1 \pm .3$ & $1.0 \pm .4$ & $0.9 \pm .1^{*}$ \\
\hline
\end{tabular}

NOTE. Data given as mean $\pm S D$. See text for methods.

Abbreviation: $\mathrm{C}_{\mathrm{s}}$, static lung compliance $\left(\mathrm{mL} / \mathrm{cm} \mathrm{H}_{2} \mathrm{O} / \mathrm{kg}\right)$.

${ }^{*} P<.05$ compared to initial compliance in each group. 
Table 4. Weights and Capillary-Alveolar Leak Indexes of Rats Ventilated at Different Tidal Volumes

\begin{tabular}{lccc}
\hline & $\begin{array}{c}\text { Group A } \\
(\mathrm{TV}=5 \mathrm{~mL} / \mathrm{kg})\end{array}$ & $\begin{array}{c}\text { Group B } \\
(\mathrm{TV}=15 \mathrm{~mL} / \mathrm{kg})\end{array}$ & $\begin{array}{c}\text { Group C } \\
(\mathrm{TV}=20 \mathrm{~mL} / \mathrm{kg})\end{array}$ \\
\hline $\begin{array}{l}\text { Wet wt/dry wt } \\
\text { Dry wt/body wt } \\
\left(\times 10^{-4}\right)\end{array}$ & $4.44 \pm .15$ & $4.44 \pm .11$ & $4.67 \pm .12^{*}$ \\
& $3.78 \pm .56$ & $3.57 \pm .28$ & $4.24 \pm .34$ \\
\hline & Group D & $\begin{array}{c}\text { Group E } \\
(\mathrm{TV}=5 \mathrm{~mL} / \mathrm{kg})\end{array}$ & $(\mathrm{TV}=20 \mathrm{~mL} / \mathrm{kg})$ \\
\hline Capillary-alveolar & & \\
leak index & 0.013 & 0.01 \\
& 0.002 & 0.006 \\
& 0.003 & 0.023 \\
& 0.02 & 0.004 \\
\hline
\end{tabular}

NOTE. Dry weight of right lung/total body weight. Capillary-alveolar leak index expressed as fluorescence of bronchoalveolar lavage fluid/ fluorescence of serum. Values given are for individual animals. Group mean: group $D-0.009 \pm 0.008$, group $E=0.011 \pm 0.008$.

${ }^{*} P<.05 \vee$ control.

creased microvascular permeability and increased microvascular filtration pressure. ${ }^{6}$

The histologic changes from $20 \mathrm{~mL} / \mathrm{kg}$ overinflation were not dramatic. Minimal perivascular edema was seen in the $20 \mathrm{~mL} / \mathrm{kg}$ group. None was seen in the animals ventilated at normal tidal volume of $5 \mathrm{~mL} / \mathrm{kg}$.

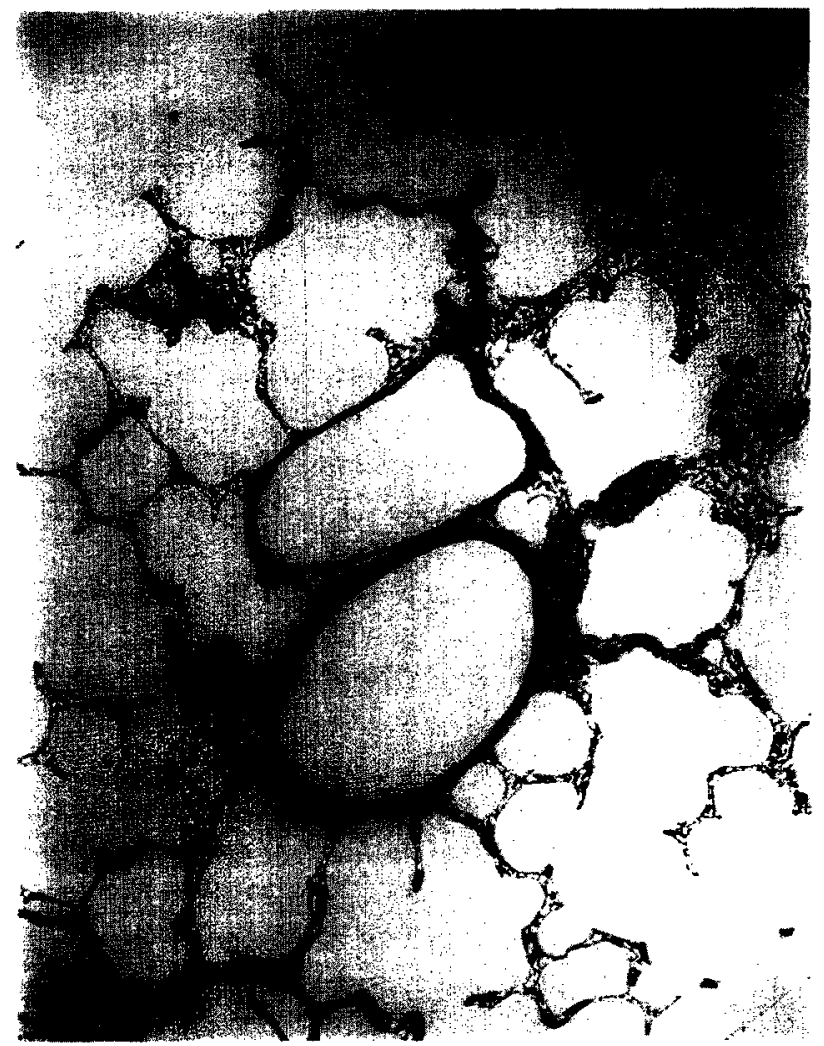

Fig 2. Lung from control animal (TV $5 \mathrm{~mL} / \mathrm{kg}$ ) showing small artery and bronchus, normal alveolar architecture and no perivascular edema (original magnification $\times 250$ ).

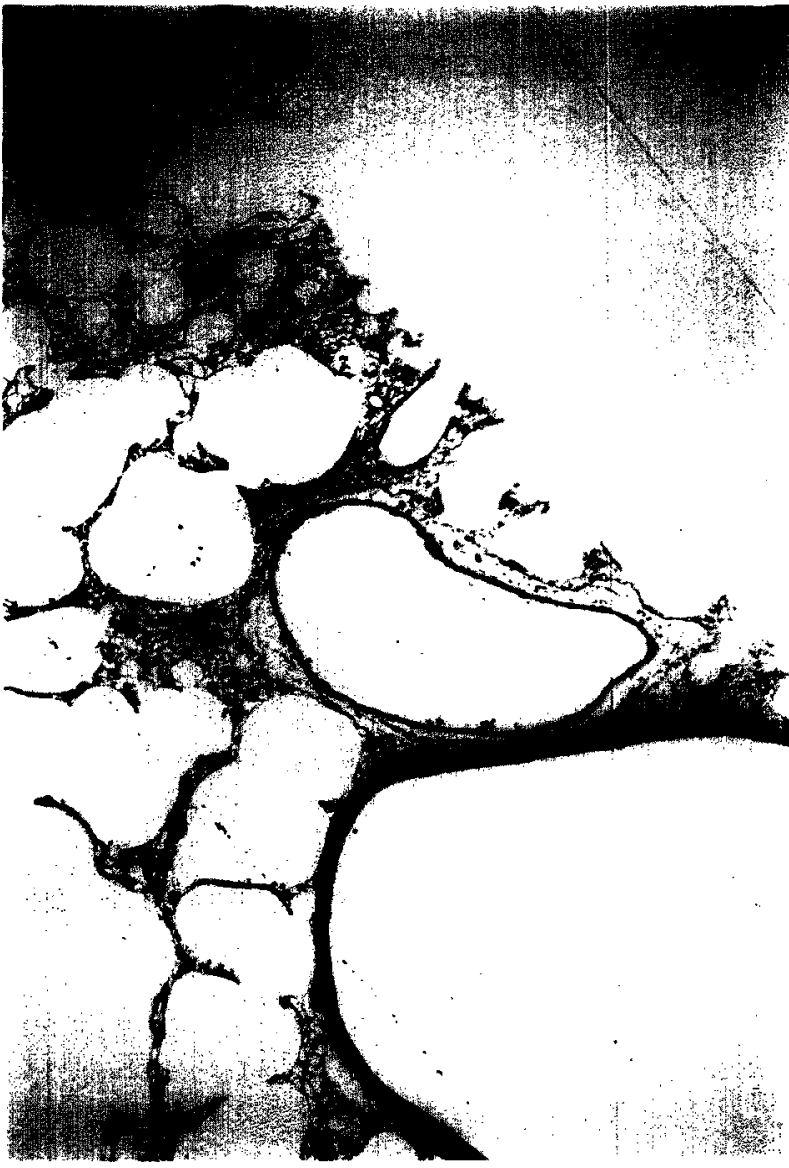

Fig 3. Lung from tidal volume $20 \mathrm{~mL} / \mathrm{kg}$ animal. Note slight edema around small artery (original magnification $\times 250$ ).

Of note, perivascular edema is the first histological change noted in the more dramatic overdistension lung injury models.

Capillary alveolar integrity was maintained as shown by the BAL fluorescence studies. This is expected, since gross pulmonary edema was not created at this minimal level of overdistension. For comparison, the fluorescent activity of BAL fluid in rats exposed to overdistension that results in severe lung injury (TV $30 \mathrm{~mL} / \mathrm{kg}$ ) is greater than 10 times that of control animals (unpublished data).

From this study it appears that the minimal level of overdistension in rats that causes an easily identifiable injury is $20 \mathrm{~mL} / \mathrm{kg}$.

Since the purpose of these experiments was to demonstrate that moderate lung overdistension directly causes lung injury, it is important to eliminate other potcntial sources of injury. The stability of the hematocrit over 4 or 5 hours of experimentation provides evidence that large intravascular fluid shifts did not occur. Likewise, central venous oxygen saturation, which closely parallels mixed venous oxygen 
saturation, is an excellent reffection of the relationship between oxygen delivery and oxygen consumption and is very sensitive to changes in cardiac output. ${ }^{10}$ Central venous oxygen saturation remained unchanged during high tidal volume ventilation indicaling that reduced cardiac output from elevated intrathoracic pressure was not responsible for the injury. Likewise arterial blood pressure and animal temperature remained stable throughout the experimental period.

The elevated $\mathrm{pO}_{2}$ during ventilation of tidal volume $20 \mathrm{~mL} / \mathrm{kg}$ underscores the fact that achieving higher $\mathrm{pO}_{2}$ during mechanical ventilation does not always mean "better." In fact, higher $\mathrm{pO}_{2}$ may be achieved at the expense of a lung injury. Although the ventilator rate was turned down during high tidal volume ventilation, animals ventilated at TV $15 \mathrm{~mL} / \mathrm{kg}$ and TV $20 \mathrm{~mL} / \mathrm{kg}$ all became hypocarbic and alkalotic. By the conclusion of the experiment animals in these two groups were slightly acidotic. It is unlikely that this slight acidosis is responsible for the lung injury seen with high tidal volume ventilation.

Several previous studies have investigated the lung injuries produced by overdistension and/or high airway pressure. In 1964, Greenfield et al investigated the effects of high lung volume mechanical ventilation on the surface tension properties of lung extracts in dogs. ${ }^{1}$ They demonstrated that PIP 10, TV $14 \mathrm{~mL} / \mathrm{kg}$ for up to 6 hours resulted in no change in surface tension properties. A PIP of 26 to $32 \mathrm{~cm} \mathrm{H}_{2} \mathrm{O}$ (TV not given, but would be in excess of $50 \mathrm{~mL} / \mathrm{kg}$ ) for 2 to 5 hours resulted in pulmonary edema. One hour of such ventilation resulted in increased surface tension when measured at 24 hours after injury. Two hours of such ventilation resulted in increased surface tension at 24 hours and visible atelectasis with return to normal surface tension at 48 hours. This study did not control for effects of hypocarbia as the respiratory rate remained unchanged during high pressure inflation.

A more systematic investigation of pressurevolume lung injury (PVLI) was performed in rats by Webb and Tierney. ${ }^{2}$ The rats were mechanically ventilated for 1 hour at different PIP and PEEP. Pressures used were 14/0,30/0,30/10, 40/0, and $45 / 10 \mathrm{~cm} \mathrm{H}_{2} \mathrm{O}$. Hypocarbia was avoided by adding dead space and changing respiratory rate. Tidal volume was estimated, not measured $(12,27,12,40$, and $15 \mathrm{~mL} / \mathrm{kg}$, respectively). Lung injury was assessed morphologically. There was a clear progression of lung injury with high pressures. PEEP protected against alveolar edema and supported oxygenation in the PIP $45 \mathrm{~cm} \mathrm{H}_{2} \mathrm{O}$ group; without PEEP, this group died at less than 1 hour. PEEP protected against alveolar flooding and pulmonary edema, and supported gas exchange, but there is no evidence of whether it protected against lung injury.

Dreyfus et al used PIP $45 \mathrm{~cm} \mathrm{H}_{2} \mathrm{O}$ for 5,10 , and 20 minutes (TV not measured) in rats to produce lung injury. ${ }^{3}$ Respiratory rate was decreased during high pressure ventilation to avoid hypocarbia, but $\mathrm{PCO}_{2}$ was not reported. With this short duration, severe injury, they demonstrated progressive increase in extravascular lung water, sodium space, dry lung weight, and increasing pulmonary vascular permeability. Morphologic injury progressed from perivascular edema to interstitial edema (with detachment of endothelial cells from their basement membranc) to alveolar edema.

Dreyfus et al later demonstrated the following in a similar 20 minute lung injury ${ }^{4}$ : (1) increased airway pressure without increased lung volume produced only slight morphologic change (PIP $45 \mathrm{~cm} \mathrm{H}_{2} \mathrm{O}$, TV $19 \mathrm{~mL} / \mathrm{kg}$, thoracoabdominal strapping); (2) highpressure, high-volume ventilation with PEEP resulted in interstitial edema and increasing microvascular permeability $\left(45 / 10 \mathrm{~cm} \mathrm{H}_{2} \mathrm{O}\right.$, TV $\left.25 \mathrm{~mL} / \mathrm{kg}\right)$; (3) high-pressure, high-volume ventilation resulted in alveolar edema as they previously reported $(45 / 0 \mathrm{~cm}$ $\mathrm{H}_{2} \mathrm{O}$, TV $40 \mathrm{~mL} / \mathrm{kg}$ ); and (4) high-volume, lowpressure ventilation resulted in a similarly severe injury (negative pressure ventilation using an "iron lung," TV $44 \mathrm{~mL} / \mathrm{kg}$ ). Control animals were ventilated at TV $13 \mathrm{~mL} / \mathrm{kg}$. There was significant hypocarbia $\left(\mathrm{PaCO}_{2}=13 \mathrm{~mm} \mathrm{Hg}\right)$. In a subsequent report, the absolute magnitude of over-distension was determined to be the most important factor in creating PVLI. ${ }^{11}$ Equivalent lung volumes at high TV (low FRC) and low TV (high FRC) produced equivalent injury.

Hernandez et al subjected closed-chested rabbits to PIP of 15,30 , and $45 \mathrm{~cm} \mathrm{H}_{2} \mathrm{O}$ for 1 hour. ${ }^{5}$ One group had chest wall restriction accomplished by application of a body cast. Chest wall restriction ablated the microvascular permeability changes as well as the gross morphologic changes of atelectasis, hemorrhage, and consolidation seen in the other rabbits at PIP of 30 and $45 \mathrm{~cm} \mathrm{H}_{2} \mathrm{O}$. Ex vivo lungs were severely damaged at PIP of 15 and $30 \mathrm{~cm} \mathrm{H}_{2} \mathrm{O}$. This study provides more evidence that lung overdistension is primarily responsible for the microvascular permeability changes of PVLI. Hypocarbia was not controlled (all respiratory rates were $25 / \mathrm{min}$, no reporting of $\mathrm{PaCO}_{2}$ ). 
Kolobow et al have demonstrated that mechanical

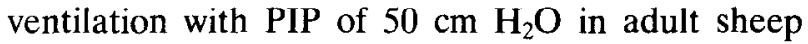
results in progressive severe lung injury when continued for 48 hours. ${ }^{7}$ Tidal volume initially increases to 40 to $50 \mathrm{~mL} / \mathrm{kg}$ and peaks at 60 to $70 \mathrm{~mL} / \mathrm{kg}$ at 2 to 6 hours, then progressively declines over the following 48 hours. He also showed that ventilation at PIP of 30 $\mathrm{cm} \mathrm{H}_{2} \mathrm{O}$ (TV $30 \mathrm{~mL} / \mathrm{kg}$ ) for 48 hours resulted in significant lung injury. ${ }^{8}$ In another study, sheep injured by PIP of $50 \mathrm{~cm} \mathrm{H}_{2} \mathrm{O}$ were managcd by conventional mechanical ventilatory support or extracorporeal carbon dioxide removal. ${ }^{12}$ The sheep injured by high PIP for 18 to 27 hours did not survive using conventional therapy whereas most treated with extracorporeal support survived. In all of their experiments, $\mathrm{pCO}_{2}$ was carefully controlled. Kolobow et al have reported in sheep with mechanical ventilator-induced lung injury, a progression of multiple organ failure similar to that seen in clinical settings. This includes an inflammatory cell infiltrate within the lungs. ${ }^{?}$

These studies show that total lung inflation volume seems to be initially the most important component of injury. Also, the progression of injury in acute PVLI follows a typical histologic pattern. Perivascular edema is followed by endothelial injury, interstitial edema, epithelial injury primarily to type I alveolar cells and finally alveolar edema. ${ }^{2,4}$

There is considerable homology of lung volume among the mammalian species providing support for the relevance of overdistension lung injury in animal models. ${ }^{13}$ However, intraspecies difference do exist. Overdistension of rat lungs with TV 30 to $40 \mathrm{~mL} / \mathrm{kg}$ above functional residue capacity causes severe lung injury, ${ }^{2,4}$ whereas dogs have been ventilated at 50 $\mathrm{mL} / \mathrm{kg}$ for 24 hours with little injury. ${ }^{14}$ Overdistension injuries in dogs have utilized pressures that resulted in tidal volumes in excess of $50 \mathrm{~mL} / \mathrm{kg}$. Adult sheep are injured at TV $30 \mathrm{~mL} / \mathrm{kg}$, while in one study newborn lambs requircd TV in cxcess of $45 \mathrm{~mL} / \mathrm{kg}$ to produce injury. 8,9

Lung injury, even when diffuse, is often inhomogeneous. Portions of even severely injured lungs may retain relatively normal mechanical properties. ${ }^{15}$ These more normal portions of the lung may be subjected to relative overdistension when positive pressure mechanical ventilation is used to support gas exchange. This relative overdistension and the injury it produces may prevent healing or induce permanent pathological changes in the lung. Outcome may be improved by limiting lung overdistension and accepting greater degrees of hypoxia and hypercarbia. ${ }^{16}$ Further study is needed to understand the mechanism of overdistension lung injury, the relationship between mechanical factors, biochemical changes, and the host response to this injury, as well as the effects of lung development and maturity on this injury. It is likely that overdistension lung injury plays a role in the progression of may forms of acute lung injury.

\section{REFERENCES}

1. Greenfield L, Ebert P, Benson D: The effect of positive pressure ventilation on surface tension properties of lung extracts. Anesthesiology 25:312-316, 1964

2. Webb H, Tierney D: Experimental pulmonary edema due to intermittent positive pressure ventilation with high inflation pressures. Am Rev Respir Dis 110:556-565, 1974

3. Dreyfus D. Basset G, Soler P, et al: Intermittent positive pressure hyperventilation with high inflation pressures produces pulmonary microvascular injury in rats. Am Rev Respir Dis 132:880-884, 1985

4. Dreyfus D, Soler P, Basset G, et al: High inflation pressure pulmonary edema. Am Rev Respir Dis 137:1159-1164, 1988

5. Hernandez L, Peevy K, Moise A, et al: Chest wall restriction limits high airway pressure-induced lung injury in young rabbits. $J$ Appl Physiol 66:2364-2368, 1989

6. Parker J, Hernandez L, Longennecker G, et al: Lung edema caused by high peak inspiratory pressure in dogs. Am Rev Respir Dis 142:321-328. 1990

7. Kolobow T, Moretti M, Fumagalli R, et al: Severe impairment in lung function induced by high peak airway pressure during mechanical ventilation. Am Rev Respir Dis 135:312-315, 1987

8. Tsuno K, Prato P, Kolobow T: Acute lung injury from mechanical ventilation at moderately high airway pressures. J Appl Physiol 69:956-961, 1990

9. Carlton D, Cummings J, Scheerer R, et al: Lung overexpan- sion increases pulmonary microvascular protein permeability in young lambs. J Appl Physiol 69:577-583, 1990

10. Musch TI, Larach DR: $\mathrm{O}_{2}$ content of blood sampled from different venous compartments of the rat. J Appl Physiol 65:988991, 1988

11. Dreyfuss D, Soler P, Saumon G: Overinflation pulmonary edema is not related to large volume swings but to the level of lung distension. Am Rev Respir Dis 139:A417, 1989

12. Borelli M, Kolobow T, Spatola R, et al: Severe acute respiratory failure managed with continuous positive airway pressure and partial extracorporeal carbon dioxide removal by an artificial membrane lung. Am Rev Respir Dis 138:1480-1487, 1988

13. 'I'enney SM, Remmers JE: Comparative quantitative morphology of the mammalian lung: diffusing area. Nature 197:54-56, 1963

14. Thornton D, Ponhold H, Butler J, et al: Effects of pattern of ventilation on pulmonary metabolism and mechanics. Anesthesiology 42:4-10, 1975

15. Gattinoni L, Pesenti A, Bombino M, et al: Relationships between lung computed tomographic density exchange, and PEEP in acute respiratory failure. Anesthesiology 69:824-832, 1988

16. Hickling K, Henderson S, Jackson R: Low mortality associated with low volume pressure limited ventilation with permissive hypercapnia in severe adult respiratory distress syndrome. Intens Care Med 16:372-377, 1990 


\section{Discussion}

J. Langer (St Louis, MO): This paper was stimulated by the very important clinical problem that we all face of lung damage from chronic ventilation. The authors used a model in the adult rat and asked the question, does mild overdistention of the lung produce lung injury. I think this is a very important question and a good model with good techniques but $I$ had a few problems interpreting the data. The first problem I had was definition of lung damage. In the abstract and in the paper, the authors state that there is a decrease in compliance in the group that received 20 $\mathrm{mL} / \mathrm{kg}$. They also noted that the compliance fell in the control group and what they really should have been comparing was the delta compliance, the delta $\mathrm{C}$ compared between group $C$ and group $A$ which would have not have been significant. So compliance really did not indicate lung damage in this study. The authors did not show any evidence of a capillary alveolar leak and they did not show any biochemical evidence of damage. The only damage that they showed was evidence by mild interstitial edema. I would like to ask Dr Cilley what the significance of this kind of injury is in the long term. The second problem that I had with interpretation of the data was the $\mathrm{pH}$ data which was shown on a slide but not really discussed. Although there initially was an alkalosis associated with one hour of hyperventilation, by the end of the five hour period, the rats in group $\mathrm{C}$ were acidotic. Since the $\mathrm{PCO}_{2}$ was not elevated in those rats at that time and the $\mathrm{PO}_{2}$ was normal, I can only assume that this was a metabolic acidosis which probably was due to hypoperfusion in the rats. I wonder if this hypoperfusion and acidosis could have contributed to or caused the lung injury. I have two other short questions. Would this study not be more relevant if it had been done in neonatal animals or animals that had pulmonary hypoplasia? And, finally, since the title volume was a calculated measurement in these rats based on an increase in delivered pressure, I wonder if this isn't really a model of barotrauma rather than over distention.

C.J.H. Stolar (New York, NY): I didn't have the opportunity to rcview the manuscript but I was struck by the apparent relationship between what you showed us in these animals and what often happens clinically. You could see how seductive it might be to increase ventilating pressures with the appropriate response in blood gas values but the apparent price that was being paid at least in this model with some changes in lung compliance. I wonder if the edema that you saw might be the precursor of static changes in the lung compliance. I think in the clinical circumstances this may be a precursor of bronchopulmonary dysplasia. Often we find that with much less aggressive ventilator settings, we don't see these kinds compliance changes in the lungs. I thought what you showed was very similar to what Dr Kolobow has shown us many times, namely that minimal ventilation of neonatal lungs produces compliance changes and interstitial infiltrates. This has lcd to some of the work that was shown clinically by Jay Wilson's group with the intratracheal ventilation as well as the ventilator strategies which are practiced at our institution, hypoventilation without regard to airway pressure or $\mathrm{CO}_{2}$. I speculate that you might find the neonatal animal more vulnerable to these distending pressures than the adult animal. I would also like you to speculate as to what relationship might exist between mechanical signals and the biochemical results.

D. Tapper (Seattle, WA): Dr Cilley, do you think if the animal is acidotic that he wouldn't also have interstitial changes that would lead to increase in interstitial water?

R.E. Cilley (response): Thank you for those questions. They are perceptive and show insight into what was presented here. Dr Langer asked, was there really a compliance change. There was a significant decrease in the high tidal volume ventilated group. However, I think the best determinant of injury is lung weight. It always correlates with microvascular permeability. I think lung weight is the best measurement of microvascular permeability changes. Group $\mathrm{C}$ was slightly more acidotic. The animals did remain stable throughout the experiment. The central venous oxygen saturation (an excellent indicator of cardiac output) remained stable from the beginning to the end of the experiment. Concerning the question of whether this is barotrauma versus over distention, I think overdistention is barotrauma. Barotrauma as conventionally understood means pneumothorax or interstitial emphysema. Barotrauma in a more expansive definition is anything that relates to overdistention or high pressures that causes lung injury. The actual level of over distention was measured and not calculated. These animals were in a plethysmograph which allowed us to measure the true tidal volume of ventilation. Dr Stolar speculates about the relationship between mechanical and biochemical factors. I, too, can only speculate because we don't have any good answers about that now. I suspect that the first step of the injury is truly mechanical and that subsequently there is an inflammatory response. The next step is to see whether the typical pathways of inflammation are actually initiated by purely a mechanical 
injury. There is some suggestive evidence of that in work that Dr Kolobow has done.

Dr Tapper, there is no question as to whether you can injure a lung by overdistending it. If you over inflate a rat's lung to $30 \mathrm{~mL} / \mathrm{kg}$ tidal volume, you will get a lethal injury. We asked, what is the smallest level of overdistention that causes injury. We didn't appear to get an injury at $15 \mathrm{~mL} / \mathrm{kg}$ tidal volume. We did get an apparent, although small injury at 20 $\mathrm{mL} / \mathrm{kg}$. You cannot extrapolate the milliliters per kilogram that it takes to injure a rat to all mammalian species. There is a great homology among the mammalian species from shrews to whales in terms of the size of their lungs proportional to the size of their body. However, there are slight differences in animals. Dugs can tolerate considerably higher tidal volumes of ventilation (up to $50 \mathrm{~mL} / \mathrm{kg}$ for extended periods of time) without apparent injury whereas in rats it is lethal in 5 minutes to use $40 \mathrm{~mL} / \mathrm{kg}$ tidal volume. 